\title{
The Effect of Extract of Canarian Nuts on Reduction of Total Cholesterol Levels of Hyperglicemic Rat
}

\author{
Reski Pebriani ${ }^{1}$, Nurhaedar Jafar ${ }^{1}$, Wahiduddin ${ }^{2}$, Healthy Hidayanti ${ }^{1}$, Burhanuddin ${ }^{1}$, Ummu \\ Salamah $^{3}$ \\ Correspondence: eda.gizi@gmail.com \\ ${ }^{1}$ Department of Nutrition Science, Faculty of Public Health, Hasanuddin University, \\ Indonesia \\ ${ }^{2}$ Department of Epidemiology, Faculty of Medical, Hasanuddin University, Indonesia \\ ${ }^{3}$ Department of Reproductive Health, Faculty of Public Health, Hasanuddin University, \\ Indonesia
}

\begin{abstract}
This study aims to determine the effect of walnut extract (Canarium indica) on the total cholesterol levels of hyperglycemic Wistar rats (Rattus norvegicus L). Experimental research with pre-post-test control design. The samples in this study were 28 rats induced by alloxan to become hyperglycemic. The test animals were divided into four groups, each consisting of seven: negative control (Na CMC 1\%), positive control (metformin $150 \mathrm{mg} / \mathrm{Kg} \mathrm{BW}$ ), walnut extract group $300 \mathrm{mg} / \mathrm{Kg} \mathrm{BW}(0.06 \mathrm{~g} / 200 \mathrm{gr} \mathrm{BW})$, and extract $600 \mathrm{mg} / \mathrm{Kg} \mathrm{BW}$ $(0.12$ / $200 \mathrm{~g} \mathrm{BW})$. The intervention was given walnut extract for 21 days. Total cholesterol levels were measured by the Easytouch Multi-Monitoring System. This study used SPSS with paired t-test and ANOVA test. The results showed a significant reduction in cholesterol levels in all groups after treatment $(\mathrm{p}<0.05)$. There was a significant difference in the reduction of total cholesterol levels between groups with a value of $p=0.037$. The results of the posthoc test showed a difference in the reduction in total cholesterol levels between the 300 extract group, $1 \% \mathrm{Na} \mathrm{CMC}$, and metformin and the 600 extract group with $1 \% \mathrm{Na} \mathrm{CMC}$ p-value $<0.05$, there was no difference between the 600 extract group and the metformin group. $p>0.05$. Walnut extract was effective in reducing alloxan-induced fasting blood sugar levels of mice. Total cholesterol levels in hyperglycemic rats experienced a significant decrease after 21 days of intervention with walnut extract 300 and $600 \mathrm{mg} / \mathrm{kg} \mathrm{BW}$, but only walnut extract at a dose of $600 \mathrm{mg} / \mathrm{kg} \mathrm{BW}$ had the same effectiveness as metformin.
\end{abstract}

Keywords: Alloxan, Canarium Indica Extract, Hyperglycemic, Total Cholesterol Levels, Rat

Received: November 7, 2020

Received in Revised: November 29, 2020

Accepted: December 13, 2020

\section{Introduction}

Diabetes mellitus is a health problem in the 21 st century. Globally, the prevalence of diabetes in 2019 is around $9.3 \%$, and the latest estimate will increase by around $0.9 \%$ in 2035 to $10.2 \%$. Hyperglycemic is an indicator of diabetes mellitus (Kaiser et al., 2018; Saeedi et al., 2019). Hyperglycemia causes impaired carbohydrate and fat metabolism. Lipid metabolism disorders caused by hyperglycemia are characterized by changes in the lipid profile in the form of increased levels of Low-Density Lipoprotein (LDL), triglycerides, total cholesterol, and decreased levels of Low-Density Lipoprotein (HDL) which are commonly referred to as hyperlipidemia (Ladeska et al., 2017). 
Hyperlipidemia or hypercholesterolemia is one of the abnormalities of the lipid fraction in the blood or better known as dyslipidemia, this condition occurs due to disorders of lipoprotein metabolism which is often called the lipid triad which consists of increased concentrations of Very Low-Density Lipoproteins (VLDL) or triglycerides, a decrease in High-Density Lipoprotein concentrations (HDL), and the formation of atherogenic Low-Density Lipoprotein (LDL) (Widhiantara, 2017).

Hyperglycemia and dyslipidemia are metabolic syndrome disorders associated with dysfunction of the endocrine system clinically called diabetes mellitus (Amawi \& Aljamal, 2012; Mohini et al, 2012; Liao et al., 2015). Diabetes mellitus occurs due to disruption of insulin secretion, insulin action, or both. Insulin disruption will have an impact on cell damage or the occurrence of an oxidative stress reaction (ROS) on the intracellularly. The increase in oxidative stress reactions triggers an increase in stress) which can activate the JNK and IKK $\beta$ / NF- $\kappa \beta$ pathways, and if this situation occurs continuously will lead to insulin resistance. If there is insulin resistance, it will have an impact on glucose metabolism where the stimulation of $\beta$ cells produces large amounts of insulin, but if $\beta$ cells are not able to overcome this situation, there will be a disturbance in glucose tolerance which triggers an increase in glucose in the blood. In addition to increasing blood glucose, insulin resistance can reduce the activity of LPL (Lipoprotein lipase) which disrupts lipoprotein metabolism causing an increase in total cholesterol (Liao et al., 2013; Krischer et al., 2017).

The content of walnuts has antioxidant compounds and unsaturated fatty acids that can reduce oxidative stress in people with hyperglycemia (Djarkasih et al., 2011). Antioxidant compounds and unsaturated fatty acids can be used as an inhibitory medium of amylase and glucosidase, and as an inhibitor of glucose absorption in the intestine, jam is a bioactive compound in walnuts that can stimulate insulin secretion and reduce hepatic glucose output and can reduce FFA which induces the glucogenesis process. Due to insulin resistance in the liver, muscles. (Kim et al., 2016). Although there have been many in vitro studies on the content of bioactive compounds, research on the effects of walnuts on the components of metabolic syndrome (fasting blood sugar and cholesterol) in experimental animals. This study aims to determine the effectiveness of walnut extract on the components of metabolic syndrome.

\section{Methods}

Fresh walnuts (Canarium indica) are obtained from Selayar Regency, South Sulawesi Province. Fresh walnuts that are still husked in the sun in a place that is protected from the sun, then grind them into powder. The walnut powder is then soaked using $96 \%$ ethanol, then stirred every 4 hours for 15 minutes, then soaked for 1x 24 hours (one day). The results of the first soaking are filtered using Whatman filter paper so that the dregs are obtained. After that, the dregs from the first immersion are pre-soaked using $96 \%$ ethanol or remaceration. The remaceration process was carried out 2 times. The results of the filtrate from all the soaks are combined then evaporated using an evaporator at a temperature of $550 \mathrm{c}$, then in a water bath with a temperature of 500c so that you get a reddish yellow thick extract.

\section{Preparation of Test Animals}

The test animals used in this study were male Wistar rats (Rattus norvegicus) 3-4 months old and weighing 180-270 grams. The test animals were obtained from the animal house of the Faculty of Pharmacy, Hasanuddin University, which were adapted for 7 days before intervention, and were given standard feed and drinking water ad libitium. The rats were fasted for 8 hours before checking blood sugar. 


\section{Experimental Design}

Twenty-eight male rats aged 3-4 months were acclimatized for one week and divided into four groups. The test animals were made in hyperglycemic conditions using alloxan-induced by intraperitoneal at $130 \mathrm{mg} / \mathrm{Kg} \mathrm{BW}$, with the previous condition fasting for 8 hours. Fasting blood sugar levels were measured 3-6 days after alloxan injection. Mice with fasting blood sugar levels> $200 \mathrm{mg} / \mathrm{dl}$ were declared hyperglycemic and used for further research. Walnut extract (300 and $600 \mathrm{mg} / \mathrm{Kg} \mathrm{BW}$ ) was administered daily for 21 days in the intervention group.

The test animals were randomly divided into four groups as follows: negative control group $(\mathrm{KN})(\mathrm{Na} \mathrm{CMC}-1 \%$ ), positive control (KP) (metformin 150mg / Kg rat BW), walnut extract $300 \mathrm{mg} / \mathrm{Kg}$ rat BW (EK1), and extract $600 \mathrm{mg} / \mathrm{Kg} \mathrm{BW}$ of rats (EK2). During the intervention process at week 3 or on day 15, and 18 interventions there were 3 mice from the $\mathrm{KN}$ group (Na CMC 1\%), KP (metformin $150 \mathrm{Kg} / \mathrm{BW}$ ), and EK2 group (walnut extract 600 $\mathrm{mg} / \mathrm{Kg} \mathrm{BW}$ ) Each animal was included in the exclusion criteria (died during the intervention) so that the number analyzed at the end of the study was 25 individuals. Total cholesterol levels were measured using the Easytouch Multi-Monitoring System, on day 12, day 15 , day 36 . Before the easy touch is used, the tool calibration is done first using a special chip on the tool.

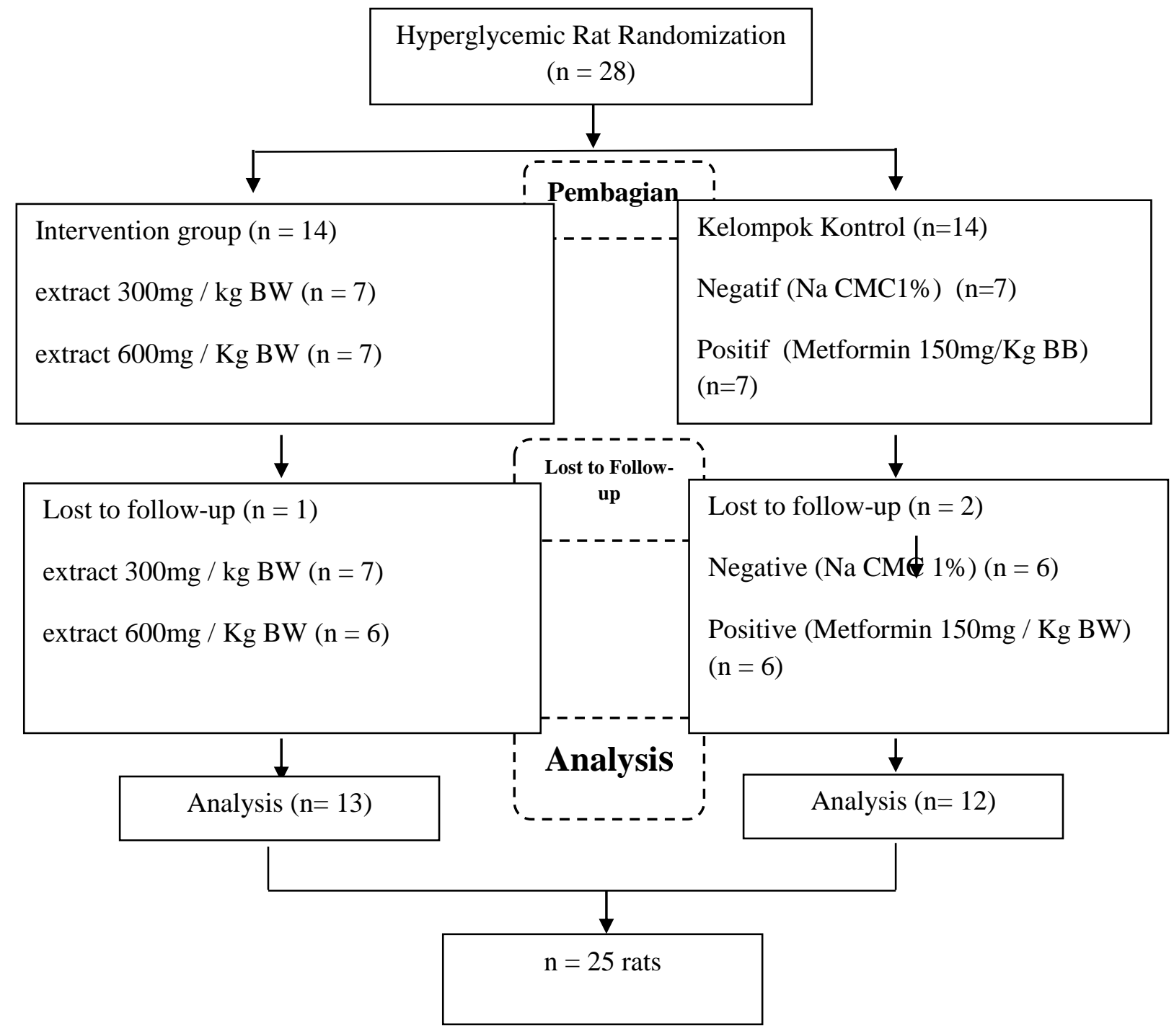




\section{Data Analysis}

Data were analyzed using the SPSS program. The data analysis technique used was paired ttest and ANOVA then followed by the LSD method which was used to determine the differences between groups. The significance was set at $\mathrm{p}<0.05$. Data presentation is done in tables and graphs. The ethical approval recommendation number in this study is $6107 /$ UN4.14.1 / TP 01.02 / 2020 and the ethical approval protocol number is 10320045002.

\section{Results and Discussion}

Graph 1. Changes in Total Cholesterol Levels

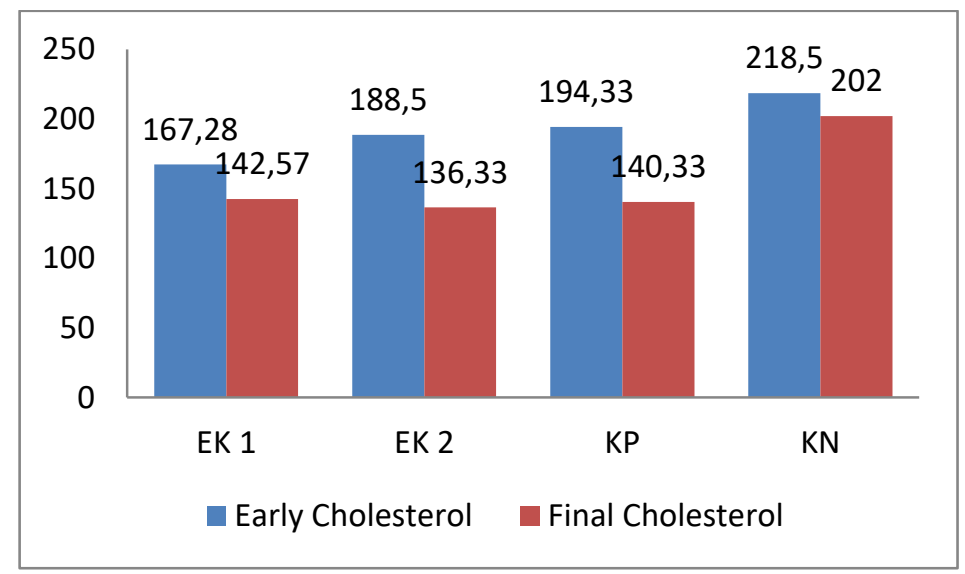

In graph 1, there was an increase in total cholesterol after the rats were said to be hyperglycemic with an average of $167 \mathrm{mg} / \mathrm{dl}$ to $218.50 \mathrm{mg} / \mathrm{dl}$. After giving the intervention for 21 days, all groups experienced a decrease in cholesterol levels. The average reduction in cholesterol was $202.00 \mathrm{mg} / \mathrm{dl}$ to $136.33 \mathrm{mg} / \mathrm{dl}$ ), the highest was in the KP group (metformin 150mg / Kg BW) $(54.00 \mathrm{mg} / \mathrm{dl}$ ), and the lowest was in the KN group (Na CMC $1 \%)(16.50 \mathrm{mg} / \mathrm{dl})$. Whereas for the EK1 and EK2 groups (extract $300 \mathrm{mg} / \mathrm{Kg} \mathrm{BW}$ and extract $600 \mathrm{mg} / \mathrm{KgBB}$ ) respectively (24.71 and $52.16 \mathrm{mg} / \mathrm{dL}$ ).

Table 1. Average Total Cholesterol Levels Pre and Post Before and After Intervention between groups

\begin{tabular}{|c|c|c|c|c|c|}
\hline Group & $\begin{array}{c}\text { Total Cholesterol } \\
\text { Levels } \\
\text { (Hyperglycemic) } \\
\text { Mean } \pm \text { SD } \\
\end{array}$ & $\begin{array}{c}\text { Total Cholesterol } \\
\text { Levels (Intervention) } \\
\text { ( } 3 \text { weeks) } \\
\text { Mean } \pm \text { SD }\end{array}$ & $\begin{array}{c}\text { P- } \\
\text { value } \\
*\end{array}$ & $\Delta$ & $\begin{array}{c}\mathbf{P} \\
\text { Value } * *\end{array}$ \\
\hline $\mathrm{KN}$ & $218,50 \pm 18,07$ & $202,00 \pm 18,18$ & 0,001 & $\downarrow 16,50$ & \multirow{4}{*}{0.037} \\
\hline $\mathrm{KP}$ & $194,33 \pm 32,65$ & $140,33 \pm 28,18$ & 0,01 & $\downarrow 54,00$ & \\
\hline EK1 & $167,28 \pm 29,31$ & $142,57 \pm 27,77$ & 0,004 & $\downarrow 24,71$ & \\
\hline EK 2 & $188,50 \pm 31,19$ & $136,33 \pm 13,06$ & 0,02 & $\downarrow 52,16$ & \\
\hline
\end{tabular}

Source: Primary Data, 2020.

The results of the Paired T-Test for all groups, both the negative group, the positive group, and the intervention group (extract 300 and extract 600) experienced a significant decrease with a p-value $<0.05$. The negative control group has a p-value of 0.0001 , then the $\mathrm{p}$-value of the positive control group is 0.004 and the provision of walnut extract at a dose of 300 and walnut extract at a dose of 600 each have a p-value of 0.004 and 0.02 , therefore the p-value the largest was the 600 extract group compared to other groups. 
The highest increase in total cholesterol in the positive group (metformin) $(86 \mathrm{mg} / \mathrm{dl}$ to $399.83 \mathrm{mg} / \mathrm{dl})$. Giving EK2 can reduce fasting blood sugar levels $(399.83 \mathrm{mg} / \mathrm{dl}$ to 98.83 $\mathrm{mg} / \mathrm{dl}$ normal). In the EK 1 group (extract 300mg / Kg BW) $(69.71 \mathrm{mg} / \mathrm{dl}$ to $382.42 \mathrm{mg} /$ $\mathrm{dl}$ ), and after the intervention for 21 days there was a decrease in fasting blood sugar levels to (134.71 mg / dl).

The change in a reduction in the KP group (metformin $150 \mathrm{mg} / \mathrm{Kg} \mathrm{BW}$ ) was not much different from the extract group. KP fasting blood sugar levels $(77.66 \mathrm{mg} / \mathrm{dl})$, post alloxan induction increased 4 times from early fasting blood sugar $(368.33 \mathrm{mg} / \mathrm{dl})$, and there was a decrease in fasting blood sugar to normal $(85.33 \mathrm{mg} / \mathrm{dl})$ for 21 days of intervention. The $\mathrm{KN}$ group ( $\mathrm{Na} \mathrm{CMC} 1 \%)$ also experienced an increase in fasting blood sugar $(174 \mathrm{mg} / \mathrm{dl})$ where the average initial blood sugar $(74.83 \mathrm{mg} / \mathrm{dl}$, became $248.83 \mathrm{mg} / \mathrm{dl})$, after treatment with $\mathrm{Na}$ CMC $1 \%$ of the KN group experienced a change in decreasing fasting blood sugar levels $(41.55 \mathrm{mg} / \mathrm{dl}$, to $207.33 \mathrm{mg} / \mathrm{dl})$.

Table 2. Comparison between LSD (Least Significant Difference) Advanced Test Groups

\begin{tabular}{|l|l|}
\hline \multicolumn{1}{|c|}{ Intergroup Comparisons } & $\boldsymbol{P}$-Value \\
\hline$E K 1$ vs $K N$ & 0,571 \\
\hline$E K 1$ vs $K P$ & 0,053 \\
\hline$E K 2$ vs $K N$ & 0,025 \\
\hline$E K 2$ vs $K P$ & 0,903 \\
\hline
\end{tabular}

Information: KN (Negative Control), KP (Positive Control) EK 1 (Walnut Extract 300), EK 2 (Walnut Extract 600)

ANOVA test showed that all groups experienced a significant decrease $(\mathrm{p}=0.037)$. In table 2 , the results of the follow-up analysis of the LSD (Least Significant Difference) test between EK1 (300 mg / Kg BW) and EK2 (600 mg / Kg BW) with the KP (metformin $150 \mathrm{mg} / \mathrm{Kg}$ $\mathrm{BW}$ ) and $\mathrm{EK} 1$ (300 $\mathrm{mg} / \mathrm{Kg} \mathrm{BW}$ ) groups ) with the $\mathrm{KN}$ group (NaCMC 1\%) there was no significant difference ( $p>0.05$ ), while the EK2 (600 mg / Kg BW) group with the KN group (Na CMC 1\%) had a significant difference ( $\mathrm{p}<0.05)$.

Total cholesterol is the amount of cholesterol carried in all cholesterol-carrying particles in the blood, including High-Density Lipoprotein (HDL), Low-Density Lipoprotein (LDL), and Very Low-Density Lipoprotein (VLDL). Cholesterol is widely distributed in all body cells, especially in nerve tissue (Naim et al., 2019).

Some literature explains that functional food can improve metabolic disorders including hyperglycemic without exception, walnuts, which contain antioxidant compounds and unsaturated fatty acids. Walnuts contain flavonoids, polyphenols, and phenolics which act as antioxidants to reduce oxidative stress in hyperglycemia (Aryaeian et al., 2017; Djarkasih et al., 2011). The content of bioactive compounds such as antioxidants in some extracts can reduce blood sugar levels through the regeneration process of pancreatic beta, decrease gluconeogenesis, and inhibit alpha-glucosidase enzyme activity, and oxidative stress (Farzaei et al., 2017; Rudianto, 2011).

During the three-week intervention, all groups experienced a significant difference in total cholesterol levels between before and after the intervention where there was a decrease in cholesterol levels with a value of $p=0.037$. This research is in line with research conducted by (Gunawan et al., 2017). that mice that have been through a high-fat diet process and then given walnut extract for 28 days can reduce total cholesterol levels with a value of $p=0.013$. 
The decrease in total cholesterol levels in the 300 and 600 extract treatment groups was due to walnut extract containing antioxidants. Based on a qualitative preliminary study, it shows that walnut extract from selayar contains bioactive or antioxidant compounds such as flavonoids, saponins, tannins, terpenoids, and alkaloids.

The mechanism of flavonoid compounds can reduce total cholesterol levels by inhibiting 3Hydroxy-3-Methyl-Glutaryl-CoenzymeA (HMG-CoA) reductase which causes a decrease in cholesterol synthesis and increases the number of LDL receptors contained in the hepatic cell membrane and extrahepatic tissue so that levels of Total cholesterol will decrease, with a decrease in total cholesterol levels, the levels of LDL which function as a means of transporting lipids in the blood will decrease (Millar et al., 2017). According to Nurarifah (2011) flavonoids can reduce cholesterol levels by reducing HMG-CoA reductase activity, reducing acyl-CoA cholesterol acyltransferase (ACAT) enzyme activity, and reducing cholesterol absorption in the digestive tract.

The experimental animal group experienced changes in total cholesterol levels where there was a decrease and there was no significant difference between the positive control group, extract 300, and 600 in terms of reducing cholesterol levels. This research is in line with research (Rochayati, 2018) which shows that metformin and giving yellow passion fruit juice can reduce total cholesterol and blood triglyceride levels of alloxan-induced diabetic mice which is then supported by other studies (Nugroho, 2013) which used positive control of metformin and extracts. Rosella can reduce cholesterol levels in hyperglycemic rats induced by alloxan. Metformin can reduce cholesterol levels to normal limits.

In addition to type 2 diabetes mellitus therapy (not dependent on insulin) which is used as monotherapy when hyperglycemia, metformin can also increase the metabolism of good fats in the liver (liver) and other tissues, including fatty acids and cholesterol system. Insulin resistance that occurs can cause many abnormalities in lipids, including increased total cholesterol, VLDL, and triglycerides, excess postprandial lipids, decreased HDL, and LDL particles become denser (Citrin et al., 2017).

The occurrence of insulin resistance will reduce the activity of lipoprotein lipase in adipose and muscle tissue so that the work of insulin in suppressing triglyceride and cholesterol synthesis and decreasing insulin secretion (Schofield et al., 2016). Metformin can increase insulin sensitivity in liver and peripheral (muscle) tissue, allowing increased glucose uptake (Dipiro et al., 2014). However, in this study, the analysis of fatty acids was not carried out in the walnut extract from Selayar, so an assessment is needed in this regard.

\section{Conclusion}

In the study, it was concluded that all groups ( $\mathrm{Na}$ CMC $1 \%$, metformin (150 mg / Kg BW), EK1 (walnut extract 300mg / Kg BW), and EK 2 (Extract 600mg / Kg BW) could reduce total cholesterol levels from induced rats. alloxan after 21 days of intervention. The highest decrease was in the metformin group and the lowest $1 \% \mathrm{Na}$ CMC group and 600 have the same ability to lower total cholesterol levels, while extract 600 is as effective as metformin in reducing total cholesterol levels.

\section{References}

Amawi, K., \& Aljamal, A. (2012). Effect of Lepidium sativum on lipid profiles and blood glucose in rats. $J$ Phys Pharm Adv, 2(8), 277-281. 
Aryaeian, N., Sedehi, S. K., \& Arablou, T. (2017). Polyphenols and their effects on diabetes management: A review. Medical Journal of the Islamic Republic of Iran, 31(1), 886-892. https://doi.org/10.14196/mjiri.31.134

Citrin, D., Mehanni, S., Acharya, B., Wong, L., Nirola, I., Sherchan, R., ... \& Le, P. (2017). Power, potential, and pitfalls in global health academic partnerships: review and reflections on an approach in Nepal. Global health action, 10(1), 1367161.

Dipiro, J. T., Talbert, R. L., Yee, G. C., Matzke, G. R., Wells, B. G., \& Posey, L. M. (2014). Pharmacotherapy: A Pathophysiologic Approach, ed. McGraw-Hill Medical, New York.

Djarkasih G.S.S., Nuraly EJN, S., \& MF, L. LE. (2011). Analysis of Bioactive Compound in Canarium Nut (Canarium Indicum L.),. Universitas Sam Ratulangi.

Farzaei, F., Morovati, M. R., Farjadmand, F., \& Farzaei, M. H. (2017). A Mechanistic Review on Medicinal Plants Used for Diabetes Mellitus in Traditional Persian Medicine. Journal of Evidence-Based Complementary and Alternative Medicine, 22(4), 944-955. https://doi.org/10.1177/2156587216686461

Gunawan, G. A., Zakaria, S. P., Fatmaningrum, W. (2017). The effect of Walnuts (Canarium indicum L.) Extract on Male Mice (Mus Musculus L.) Undergo Total Cholestrol Induced By Higt-Fat Diet. Thesis, Universitas Airlangga.

Kaiser, A. B., Zhang, N., \& Van Der Pluijm, W. (2018). Global Prevalence Of Type 2 Diabetes Over The Next Ten Years. American Diabetes Association. http://doi.org/10.2337/db18-202-LB

Kim, Y., Keogh, J. B., \& Clifton, P. M. (2016). Polyphenols and glycemic control. Nutrients, $8(1), 17$.

Krischer, J. P., Schatz, D. A., Bundy, B., Skyler, J. S., \& Greenbaum, C. J. (2017). Effect of oral insulin on prevention of diabetes in relatives of patients with type 1 diabetes: a randomized clinical trial. Jama, 318(19), 1891-1902.

Ladeska, V., Dwita, L. P., \& Febrina, S. (2017). Potensi Ekstrak Etanol 70\% Daun Sukun (Artocarpus altilis) Terhadap Penurunan Kadar Glukosa Darah Pada Tikus Hiperglikemia dan Hiperlipidemia. Prosiding Seminar Nasional POKJANAS TOI ke-52 Tahun 2017, (April), pp. 12-13.

Liao, P. J., Xie, R. B., Yin, R. X., Wei, D. X., Huang, J., Huang, F., \& Pan, S. L. (2015). Serum lipid profiles, the prevalence of dyslipidemia and the risk factors in two isolated Chinese minorities. International journal of clinical and experimental medicine, 8(10), 19200.

Millar, C. L., Duclos, Q., \& Blesso, C. N. (2017). Effects of dietary flavonoids on reverse cholesterol transport, HDL metabolism, and HDL function. Advances in Nutrition, $8(2), 226-239$.

Mohini, P., Subhash, P., Manohar, P., Abhijit, T., \& Vijay, N. (2012). Effect of thespesonevanadium complex in alloxan induced diabetic rats. African Journal of Pharmacy and Pharmacology, 6(10), 692-697.

Naim, M. R., Sulastri, S., \& Hadi, S. (2019). Gambaran Hasil Pemeriksaan Kadar Kolesterol Pada Penderita Hipertensi Di Rsud Syekh Yusuf Kabupaten Gowa. Jurnal Media Laboran, Volume, 9(2). 
Nugroho, C. A. (2013). Aktivitas hipokolesterolimik ekstrak rosela (Hibiscus sabdariffa) pada tikus putih diabetes. Widya Warta: Jurnal Ilmiah Universitas Katolik Widya Mandala Madiun, 36(01), 1-14.

Nurarifah, A., Suryaningrum, L. D., \& Ked, S. (2020). Pengaruh Propoelixtm Terhadap Kadar Kolesterol Total Darah Pada Tikus Strain Wistar Albino Model Dislipidemia. Thesis, Universitas Muhammadiyah Surakarta.

Rochayati, D. (2018). Pengaruh Pemberian Sari Buah Markisa Kuning (Passiflora Edulis Var. Flavicarpa) Terhadap Kadar Kolesterol Total Dan Trigliserida Mencit Diabetes Yang Diinduksi Aloksan. Universitas Jember.

Rudianto, A. D. (2011). Konsnsus Pengelolaan dan Pencegahan Diabetes Melitus Tipe 2 di Indonesia 2011.

Saeedi, P., Petersohn, I., Salpea, P., Malanda, B., Karuranga, S., Unwin, N., Colagiuri, S., Guariguata, L., Motala, A. A., Ogurtsova, K., Shaw, J. E., Bright, D., \& Williams, R. (2019). Withdrawn: Global and regional diabetes prevalence estimates for 2019 and projections for 2030 and 2045: results from the International Diabetes Federation Diabetes Atlas, 9th edition. Diabetes Research and Clinical Practice, xxxx, 107843. https://doi.org/10.1016/j.diabres.2019.107843.

Schofield, J. D., Liu, Y., Rao-Balakrishna, P., Malik, R. A., \& Soran, H. (2016). Diabetes dyslipidemia. Diabetes Therapy, 7(2), 203-219.

Widhiantara, I. G. (2017). Terapi Testosteron Meningkatkan Jumlah Sel Leydig dan Spermatogenesis Mencit (Mus Musculus) yang Mengalami Hiperlipidemia. Jurnal media sains, 1(2), 77-83. 